\title{
Analisis Laporan Keuangan Untuk Menilai Kinerja Di PT. Indoneisa Kenderaan Terminal,Tbk. Yang Terdaftar Di Bursa Efek Indoneisa Periode 2015-2019
}

\author{
Heri Enjang Syahputra \\ Program Studi Akuntansi, Fakultas Ekonomi dan Ilmu Sosial, USM-Indonesia \\ E-mail : hensapura@gmail.com
}

\begin{abstract}
This study aims todetermine and analyze in measuring the level of financial performance at PT. Indonesia Kendaraan Terminal Tbk, 2015-2019 period in terms of financial ratio analysis.

Information on the level of financial performance is very important in maintaining the company's existence from competition. The analytical method used is descriptive method with a quantitative approach, with data collection techniques in the form of documentary research or Its kind, as well as data collection from the Indonesian Stock Exchange (BEI). The data analyzed were the financial statements of PT. Indonesia Kendaran Teminal Tbk. Namely the income statement and statement of financial position (BalanceSheet) for the period of 2015-2019. Assessment of the level of performance from the financial aspect uses financial ratio indicators, namely Current Ratio, Cash Ratio, Debt Ratio, Debt to Equity Ratio, Gross Profit Margin, Net Profit Margin, Return On Equity, Total Asset Turnover, Fixed Asset Turnover. Results of The research on the level of financial performance of PT. Indonesia Vehicle Terminal Tbk. Obtained a healthy predicate with the AA category consecutively during the period 2015 to 2019.
\end{abstract}

\section{Keyword : Financial Ratio, Financial Performance, Indonesia Stock Exchange}

\begin{abstract}
Abstrak
Penelitian ini bertujuan untuk mengetahui dan menganalisis dalam pengukuran tingkat kinerja keuangan pada PT. Indonesia Kendaraan Terminal Tbk, periode tahun 2015-2019 ditinjau dari analisis rasio keuangan. Informasi tingkat kinerja keuangan merupakan suatu yang sangat penting dalam menjaga eksistensi perusahaan dari persaingan. Metode analisis yang digunakan metode deskriptif dengan pendekatan kuantitatif, dengan teknik pengumpulan data berupa Penelitian Dokumentasi atau sejenisnya, serta Pengambilan data dari Burna Efek Indonesia (BEI). Data yang dianalisis adalah laporan keuangan PT. Indonesia Kendaran Teminal Tbk. Yaitu laporan laba rugi dan laporan posisi keuangan (Neraca) periode 2015-2019. Penilaian tingkat kinerja dari aspek keuangan menggunakan indikator rasio keuangan yaitu Current Ratio, Cash Ratio, Debt Ratio, Debt to Equity Ratio, Gross Profit Margin, Net Profit Margin, Return On Equity, Total Asset Turnover, Fixet Asset Turnover. Hasil Penelitian tingkat kinerja keuangan PT. Indonesia Kendaraan Terminal Tbk. Memperoleh Predikat sehat dengan kategori AA secara berturutturut selama periode tahun 2015 sampai dengan 2019.
\end{abstract}

Kata Kunci : Rasio Keuangan, Kinerja Keuangan, Bursa Efek Indonesia

\section{PENDAHULUAN}

Masalah keuangan merupakan salah satu masalah yang sangat vital bagi perusahaan dalam perkembangan bisnis disemua perusahaan. Salah satunya tujuan utama didirikannya perusahaan adalah untuk memperoleh keuntungan yang maksimal. Namun berhasil tidaknya perusahaan dalam mencari keuntungan dan mempertahankan perusahaannya tergantung pada manajemen keuangan. Perusahaan harus memilki kinerja keuangan yang sehat dan efesien untuk mendapatkan keuntungan atau laba. Oleh sebab itu, kinerja keuangan merupakan hal yang penting bagi setiap perusahaan didalam persaingan bisnis untuk mempertahankan perusahaannya. 
Kemampuan perusahaan dalam menghasilkan keuntungan adalah kunci keberhasilan perusahaan untuk dapat dikatakan mempunyai kinerja perusahaan yang baik, karena keuntungan merupakan komponen laporan keuangan yang digunakan sebagai alat untuk menilai baik tidaknya kinerja perusahaan. Hal ini akan mempengaruhi keberlangsungan perusahaan untuk maju dan kerjasama antara perusahaan yang satu dengan perusahaan yang lain. Salah satu faktor yang dapat menunjukkan bagaimana kinerja perusahaan itu baik dan tidak yaitu dengan analisis laporan keuangan.

Perusahaan perlu melakukan analisis laporan keuangan karena laporan keuangan digunakan untuk menilai kinerja perusahaan, dan digunakan untuk membandingkan kondisi perusahaan dari tahun sebelumnya dengan tahun sekarang apakah perusahaan terus meningkat atau tidak sehingga perusahaan mempertimbangkan keputusan yang akan diambil untuk tahun yang akan datang sesuai dengan kinerja perusahaanya. Kinerja adalah sesuatu yang ingin dicapai, untuk melakukan sesuatu yang ingin dicapai oleh seseorang. Jadi kinerja perusahaan adalah proses pengkajian secara kritis terhadap keuangan perusahaan untuk memberikan solusi dalam pengambilan suatu keputusan yang tepat pada suatu periode tertentu.

Analisis laporan keuangan menggunakan perhitungan rasio-rasio agar dapat mengevaluasi keadaan finansial perusahaan dimasa lalu, sekarang, dan masa yang akan datang. Rasio dapat dihitung berdasarkan sumber datanya yang terdiri dari rasio-rasio neraca yaitu rasio yang disusun dari data yang berasal dari neraca, rasio-rasio laporan laba rugi, dan rasio-rasio antar laporan yang disusun dari data yang berasal dari data neraca dan laporan laba-rugi. Laporan keuangan perlu disusun untuk mengetahui apakah kinerja perusahaan tersebut meningkatkan atau tidak sehingga perusahaan mempertimbangkan keputusan yang akan diambil untuk tahun yang akan datang sesuai dengan kinerja perusahaannya. Kinerja adalah sesuatu yang ingin dicapai, untuk melakukan sesuatu yang ingin dicapai oleh seseorang.Jadi kinerja perusahaan adalah proses pengkajian secara kritis terhadap keuangan perusahaan untuk memberikan solusi dalam pengambilan suatu keputusan yang tepat pada suatu periode tertentu.

Analisis laporan keuangan menggunakan perhitungan rasio-rasio agar dapat mengevaluasi keadaan finansial perusahaan dimasa lalu, sekarang, dan masa yang akan datang. Rasio dapat dihitung berdasarkan sumber datanya yang terdiri rasio-rasio neraca yaitu rasio yang disusun dari data yang berasal dari neraca, rasio-rasio laporan laba-rugi yang disusun dari data yang berasal dari perhitungan laba-rugi, dan rasio-rasio antar laporan yang disusun berasal dari data neraca dan laporan laba-rugi. Laporan keuangan perlu disusun untuk mengetahui apakah kinerja perusahaan tersebut meningkat atau bahkan menurun dan didalam menganalisis laporan keuangan diperlukan alat analisis keuangan, salah satunya adalah dengan menggunakan rasio-rasio keuangan. Rasio keuangan tersebut meliputi rasio likuiditas, rasio solvabilitas, rasio profitabilitas dan rasio aktivitas.

PT. Indonesia Kendaraan Terminal Tbk. tidak lepas dari usaha yang bertujuan untuk memperoleh keuntungan dalam menghasilkan efektifitas dan efisiensi pengelolaan keuangan. PT. Indonesia Kendaraan Terminal Tbk. dalam mengetahui kondisi keuangan perusahaannya perlu adanya penilaian kinerja keuangan dengan menggunakan berbagai macam rasio, yaitu rasio likuiditas, rasio solvabilitas, rasio profitabilitas, dan rasio aktivitas untuk pertimbangan dalam pengambilan keputusan untuk masa yang akan datang. Dari latar belakang masalah tersebut makan penulis mengambil judul "Analisis Laporan Keuangan Untuk Menilai Kinerja Di Pt. Indonesia Kendaraan Terminal Tbk. Yang Terdaftar Di Bursa Efek Indonesia Periode 2015-2019" 


\section{LANDASAN TEORI}

\section{a. Teori Laporan Keuangan}

Menurut beberapa ahli: Laporan keuangan adalah informasi yang disajikan untuk membantu stokeholders dalam membuat keputusan sosial, politik dan ekonomi, shingga keputusan yang diambil bisa berkualitas (Mahmudi, 2007:11).

Laporan keuangan perusahaan merupakan salah satu sumber informasi lain seperti informasi industri, kondisi perekonomian, pangsa pasar, perusahaan, kualitas manajemen dan lainnya (Hanafi dan Halim, 2003:49).

Laporan keuangan menggambarkan dampak keuangan dari transaksi dan peristiwa lain yang diklasifikasikan dalam beberapa kelompok besar menurut karakteristik ekonomi, yang merupakan unsur laporan keuangan (Prastowo dan Juliati, 2002:8).

\section{b. Teori Analisis Laporan Keuangan}

Analisis Laporan Keuangan (financial statement analysis) adalah aplikasi dari alat dan teknik analitis untuk laporan keuangan bertujuan umum dan data-data yang berkaitan untuk menghasilkan estimasi dan kesimpulan yang bermanfaat dalam analisis bisnis (K.R. Subramanyam dan John J. Wild, 2014:4).

Analisis laporan keuangan merupakan suatu proses membedah-bedah laporan keuangan ke dalam komponen-komponennya. Analisis keuangan pada hakikatnya bertujuan untuk memberikan dasar pertimbangan yang lebih layak dan sistematis dalam rangka memprediksi apa yang mungkin akan terjadi di masa datang, mengingat data yang disajikan oleh laporan keuangan menggambarkan apa yang terjadi. Selama itu, analisis keuangan juga akan mampu mengurangi dan mempersempit berbagai ketidakpastian (Prastowo dan Juliati, 2002:55).

Menurut Sumarso (2002:21), analisis laporan keuangan (financial statement analysis) pada hakikatnya adalah menghubungkan angka-angka yang terdapat dalam laporan keuangan dengan angka lain atau menjelaskan arah perubahan (trend)nya.

Analisis laporan keuangan berarti melakukan penelaahan atau mempelajari hubunganhubungan dan tendensi atau kecenderungan (trend) untuk menentukan posisi keuangan dan hasil operasi serta perkembangan perusahaan yang bersangkutan (falikhatun dan nugrahaningsih,2007:6).

\section{c. Teori Analisis Rasio Keuangan}

Salah satu cara untuk melakukan analisis keuangan adalah dengan cara mempelajari hubungan antara berbagai perkiraan-perkiraan dalam laporan keuangan. Hubungan anatara pos-pos tersebut dinyatakan dengan angka yang disebut dengan rasio. Rasio-rasio ini penting bagi analisis intern maupun ekstern dan menilai perusahaan dari laporan keuangan yang diumumkan perusahaan.

Analisis rasio dapat mengungkapkan hubungan penting dan menjadi dasar perbandingan dalam menemukan kondisi dan tren yang sulit untuk dideteksi dengan mempelajari masing-masing komponen yang membentuk rasio. Rasio menggambarkan suatu hubungan atau perlambangan antara suatu jumlah tertentu dengan jumlah lain, dan dengan menggunakan alat analisis berupa rasio yang akan menjelaskan atau menggambarkan kepada penganalisis baik atau buruknya keadaan posisi keuangan suatu perusahaan.

Dari definisi diatas, maka dapat disimpulkan analisis rasio keuangan adalah teknik atau alat untuk mengukur preatasi perusahaan dalam hal menentukan tingkat likuiditas, solvabilitas, keefektifan operasi serta derajat keuntungan perusahaan dengan menghubungkan antara pos-pos dalam neraca atau laporan laba rugi atau kombinasi dari keduanya. 


\section{d. Jenis-Jenis Rasio Keuangan}

Rasio keuangan didesain untuk memperlihatkan hubungan antarakun pada laporan keuangan (neraca dan laporan laba rugi). Menurut Agus Sartono (2010: 114) membagi 4 jenis analisis rasio keuangan yang digunakan dalam penilaian kinerja keuangan perusahaan, yaitu:

\section{Rasio Likuiditas (Liquidity Ratio)}

Masalah Likuiditas berhubungan dengan masalah kemampuan perusahaan dalam memenuhi kewajiban finansialnya yang harus segera dipenuhi. Likuiditas perusahaan menunjukkan kemampuan untuk membayar kewajiban finansial jangka pendek tepat pada waktunya.

Likuiditas perusahaan ditunjukkan oleh besar kecilnya aktiva lancar yaitu aktiva yang mudah untuk diubah menjadi kas yang meliputi kas, surat berharga, dan persediaan.

Jenis-jenis rasio likuiditas yang dapat digunakan oleh perusahaan untuk mengukur tingkat kemampuannya menurut kasmir (2013:134) dapat dijabarkan yaitu:

a) Rasio Lancar (Current Ratio);

Rasio ini dihitung dengan membagi aset lancar dengan kewajiban lancar. Aset lancar meliputi kas, efek yang dapat diperdagangkan, piutang usaha, dan persediaan. Jika suatu perusahaan mengalami kesulitan keuangan, perusahaan mulai lambat dalam membayar tagihan (utang usaha), tagihan bank, dan kewajiban

Lainnya yang akan meningkatkan kewajiban lancar. Jika kewajiban lancar tinggi dibandingkan aset lancar, maka current ratio akan turun, dan ini merupakan pertanda adanya masalah.

Current Ratio (Rasio Lancar) dapat dihitung dengan rumus :

$$
\text { Current Ratio }=\frac{\text { Current asset }}{\text { Current Liabilities }} \times 100 \%
$$

b) Rasio cepat (Quick ratio) atau Acid test ratio

Menurut Kasmir (2013:137) definisi Rasio cepat (Quick ratio) adalah: "Rasio cepat (Quick ratio) merupakan rasio uji cepat yang menunjukkan kemampuan perusahaan membayar kewajiban jangka pendek dengan aktiva lancar tanpa memperhitungkan nilai sediaan (inventory)". Rasio Cepat (Quick Ratio) dapat dihutung dengan rumus

$$
\text { Quick Ratio }=\frac{\text { Current Asset }- \text { Inventory }}{\text { Current Liabilities }} \times 100 \%
$$

c) Rasio kas (Cash Ratio)

Menurut I Made Sudana (2011:21) cash ratio adalah: “cash ratio merupakan kemampuan kas dan surat berharga yang dimiliki perusahaan untuk menutup utang lancar".

Rasio kas (Cash Ratio) dapat dihitung dengan menggunakan rumus

$$
\text { Cash Ratio }=\frac{\text { kas }+ \text { bank }+ \text { Surat Berharga j.Pendek }}{\text { Current Liabilities }} \times 100 \%
$$


d) Rasio Perputaran Kas (Cash Turn Over)

Menurut Kasmir (2013:140) menyatakan cash turn over sebagai berikut: "Rasio perputaran kas (cash turn over) bermanfaat untuk mengukur tingkat kecukupan modal kerja perusahaan yang dibutuhkan untuk membayar tagihan dan membiayai penjualan".

Rasio perputaran kas (Cash Turn Over) dapat dihitung dengan menggunakan rumus:

$$
\text { Cash Turn Over }=\frac{\text { Penjualan Bersih }}{\text { Modal kerja Bersih }} \times 100 \%
$$

\section{e) Inventory to net Working Capital}

Menurut Kasmir (2013:142) inventory to net working capital adalah : "rasio yang digunakan untuk atau membandingkan antara jumlah sediaan yang ada dengan modal kerja perusahaan".

Inventory to net Working Capital dapat dihitung dengan menggunakan rumas:

$$
\text { Investory to net working capital }=\frac{\text { Inventaris }}{\text { Modal } \text { kerja }} \times 100 \%
$$

\section{Rasio Solvabilitas (Leverage Ratio)}

Rasio solvabilitas atau leverage merupakan penggunaan aktiva atau dana dimana untuk penggunaan tersebut harus menutup atau membayar bebab tetap. Solvabilitas tersebut menunjukkan proporsi atas penggunaan utang untuk membiayai investasinya.

Adapun jenis-jenis rasio yang ada dalam rasio solvabilitas menurut Kasmir (2013: 155) antara lain:

a. Debt to Asset Ratio (Debt Ratio);

Debt Ratio menunjukkan seberapa besar total aset yang dimiliki perusahaan yang didanai oleh seluruh krediturnya. Semakin tinggi debt ratio akan menunjukkan semakin berisiko perusahaan karena semakin besar utang yang digunakan untuk pembelian asetnya.

Debt Ratio dapat dihitung menggunakan rumus sebagai berikut:

$$
\text { Debt ratio }=\frac{\text { Total Hutang }}{\text { Total Aset }} \times 100 \%
$$

\section{b. Debt to Equity Ratio}

Menurut Kasmir ( 2013:157) debt to equity ratio (DER) adalah: "Debt to Equity Ratio merupakan rasio yang digunakan untuk menilai utang dengan ekuitas. Untuk mencari rasio ini dengan cara membandingkam antara seluruh utang, termasuk utang lancar dengan seluruh ekuitas". Debt to Equity Ratio (DER) dapat dihitung dengan menggunakan rumus:

$$
\text { Debt ratio }=\frac{\text { Total Hutang }}{\text { Total Modal }} \times 100 \%
$$

\section{c. Long Term Debt to Equity Ratio;}

Menurut Kasmir (2013;159) Long Term Debt to Equity Ratio adalah: “Long Term Debt to Equity Ratio merupakan rasio antara utang jangka panjang dengan modal sendiri. Tujuannya adalah untuk mengukur berapa bagian dari setiap rupiah modal sendiri yang dijadikan jaminan utang jangka panjang dengan cara membandingkan antara utang jangka panjang dengan modal sendiri yang disediakan oleh perusahaan". 
Long Term Debt to Equity Ratio dapat dihitung dengan menggunakan rumus:

Long Term Debt to Equity Ratio

$=\frac{\text { Total Hutang jangka panjang }}{\text { Total Modal }} \times 100 \%$

\section{d. Times Interest Earned Ratio}

Menurut kamsir (2013:160) time interest earned ratio adalah: "Rasio untuk mengukur sejauh mana pendapatan dapat menurun tanpa membuat perusahaan merasa malu karena tidak mampu membayar biaya bunga tahunannya".

Times interest earned ratio dapat dihitung menggunakan rumus:

Times interest earnedratio

Laba sebelum pajak dan bunga

$=\frac{\text { beban bunga }}{100 \%}$

e. Fixed Charge Coverage Ratio (Rasio lingkup biaya tetap).

Menurut Kasmir (2013:162) fixed charge coverage adalah: "Fixed Charge Coverage Ratio (Rasio lingkup biaya tetap) merupakan rasio yang digunakan menyerupai rasio times interest earned. Hanya saja perbedaannya adalah rasio ini dilakukan apabila perusahaan memperoleh utang jangka panjang atau menyewa aktiva berdasarkan kontrak sewa (lease contract). Biaya tetap merupakan biaya bunga ditambah kewajiban sewa tahunan atau jangka panjang”.

Fixed Charge Coverage Ratio dapat dihitung dengan menggunakan rumus:

Fixed Charge Coverage Ratio

$\stackrel{\text { Laba sebelum pajak + biaya bunga }+ \text { kewajiban sewa }}{x 100 \%}$

biaya bunga + kewajiban sewa

\section{Rasio Profitabilitas (Profitability Ratio)}

Menurut Agus Sartono (2010:122) menyatakan sebagai berikut: "Profitabilitas adalah kemampuan perusahaan memperoleh laba dalam hubungannya dengan penjualan, total aktiva maupun modal sendiri".

Jenis-jenis rasio profitabilitas adanya 6 yang digunakan untuk menilai tingkat profitabilitas yakni terdiri dari:

a. Gross Profit Margin (Margin Laba Kotor)

Margin laba kotor atau disebut Gross Profit Margin bagian dari rasio profitabilitas memiliki tujuan untuk mengukur seberapa efisienkah usaha yang dilakukan manajemen dalam menekan HPP (harga pokok penjualan atau pembelian).

Gross Profit Margin (Margin Laba Kotor) dapat dihitung dengan menggunakan rumus:

Gross Profit Margin $=\frac{\text { Laba kotor }}{\text { penjualan bersih }} \times 100 \%$

\section{b. Net Profit Margin (NPM)}

Menurut Kasmir (2012:200) Net Profit Margin (NPM) merupakan: "rasio yang digunakan untuk mengukur margin laba atas penjualan, rasio ini akan menggambarkan penghasilan bersih perusahaan berdasarkan total penjualan”. 
Net Profit Margin dapat dihitung dengan menggunakan rumus:

$$
\text { Net Profit Margin }=\frac{\text { Laba besih }}{\text { penjualan bersih }} \times 100 \%
$$

\section{c. Return On Assets (ROA)}

Menurut Agus Sartono (2010:123) Return On Assets (ROA) merupakan: "Menunjukkan kemampuan perusahaan menghasilkan laba dari aktiva yang dipergunakan".

Semakin tinggi tingkat Return On Assets (ROA), maka akan memberikan efek terhadap volume penjualan saham, artinya tinggi rendahnya Return On Assets (ROA) akan mempengaruhi volume penjualan saham perusahaan begitu pula sebaliknya.

Return On Assets (ROA) dapat dihitung dengan menggunakan rumus:

$$
\text { Return On Assets }=\frac{\text { Laba bersih setelah pajak }}{\text { Total Assets }} \times 100 \%
$$

\section{d. Return On Equity ( ROE )}

Menurut Agus Sartono (2010:124) Return On Equity (ROE) adalah: "Mengukur kemampuan perusahaan memperoleh laba yang tersedia bagi pemegang saham perusahaan".

Return On Equity (ROE) dapat dihitung dengan menggunakan rumus:

$$
\text { Return On Equity }=\frac{\text { Laba bersih }}{\text { Ekuitas }} \times 100 \%
$$

\section{e. Earnings per Share (EPS)}

Menurut Kasmir (2013:207) Earnings per Share (EPS) sebagai berikut: "Rasio yang menggambarkan jumlah uang yang akan dihasilkan dari setiap lembar saham biasa yang dimiliki investor".

Earnings per Share (EPS) dapat dihitung dengan menggunakan rumus:

Earnings per Share $=\frac{\text { Laba bersih }}{\text { Jumlah lembar saham }} \times 100 \%$

\section{Rasio Aktivitas (Activity Ratio)}

Rasio aktivitas adalah rasio yang mengukur seberapa efektif perusahaan dalam memanfaatkan semua sumber daya yang ada padanya. Mnurut Kasmir (2012) " Rasio aktivitas (activity ratio) merupakan rasio yang digunakan untuk mengukur efektivitas perusahaan dalam menggunakan aktiva yang dimilikinya”.

Menurut Kasmir (2012) beberapa jenis-jenis rasio aktivitas lain:

1. Perputaran Piutang (Receivable Turn Over)

Jenis rasio keuangan aktivitas yang digunakan untuk mengukur berapa lama penagihan piutang selama satu periode atau berapa kali dana yang ditanam dalam piutang ini berputar dalam satu periode. Semakin tinggi rasio menunjukkan bahwa modal kerja yang ditanamkan dalam piutang semakin rendah (bandingkan dengan rasio tahun sebelumnya) dan tentunya kondisi ini bagi perusahaan semakin baik. Sebaliknya jika rasio semakin rendah ada over invesment dalam piutang. Hal yang jelas adalah rasio perputaran piutang memberikan pemahaman tentang kualitas dan kesuksesan penagihan piutang. 
Perputaran Piutang (Receivable Turn Over) dapat dihitung dengan menggunakan rumus:

$$
\text { Receivable Turn Over }=\frac{\text { penjualan } k r e d i t}{\text { piutang }} \times 100 \%
$$

\section{Perputaran Sediaan (Inventory Turn Over)}

Jenis rasio keuangan aktivitas yang digunakan untuk mengukur berapa kali dana yang ditanam dalam persediaan (Inventory) ini berputar dalam suatu periode. Rasio ini dikenal dengan nama rasio perputaran persediaan (Inventory turn over) dapat diartikan pula bahwa perputaran sediaan merupakan rasio yang menujukkan berapa kali jumlah barang sediaan diganti dalam satu tahun. Semakin kecil rasio ini, semakin jelek demikian pula sebaliknya.

Perputaran Sediaan (Inventory Turn Over) dapat dihitung dengan menggunakan rumus:

$$
\text { Inventory turn over }=\frac{\text { penjualan }}{\text { persediaan }} \times 100 \%
$$

\section{Perputaran Modal Kerja (Working Capital Turn Over)}

Jenis rasio keuangan aktivitas yang digunakan untuk mengukur atau menilai keefektifitas modal kerja perusahaan selama periode tertentu. Artinya seberapa banyak modal kerja perusahaan berputar selama suatu periode atau dalam suatu periode. Untuk mengukur rasio ini kita membandingkan antara penjualan dengan modal kerja atau dengan modal kerja rata-rata. Dari hasil penilaian, apabila perputaran modal kerja yang rendah, dapat diartikan perusahaan sedang kelebihan modal kerja. Hal ini mungkin disebabkan karena rendahnya perputaran persediaan atau piutang atau saldo kas yang terlalu besar. Demikian pula sebaliknya jika perputaran modal kerja tinggi, mungkin disebabkan tingginya perputaran persediaan atau perputaran piutang atau saldo kas yang terlalu kecil.

Perputaran Modal Kerja (Working Capital Turn Over) dapat dihitung dengan menggunakan rumus:

$$
\text { Working Capital turn over }=\frac{\text { penjualan bersih }}{\text { modal kerja }} \times 100 \%
$$

\section{Perputaran Aktiva Tetap (Fixed asset turn over)}

Jenis rasio keuangan aktivitas yang digunakan untuk mengukur beberapa kali dana yang ditanamkan dalam aktiva tetap berputar dalam satu periode. Atau dengan kata lain, untuk mengukur apakah perusahaan sudah menggunakan kapasitas aktiva tetap sepenuhnya atau belum. Untuk mencari rasio ini caranya adalah membandingkan antara penjualan bersih dengan aktiva tetap dalam suatu periode.

Perputaran Aktiva Tetap (Fixed asset turn over) dapat dihitung dengan menggunakan rumus:

$$
\text { Fixed asset turn over }=\frac{\text { penjualan }}{\text { Total aktiva tetap }} \times 100 \%
$$




\section{Perputaran Aktiva (Total Assets Turn Over)}

Jenis rasio keuangan aktivitas yang digunakan untuk mengukur perputaran semua aktiva yang dimiliki perusahaan dan mengukue berapa jumlah penjualan yang diperoleh dari tiap rupiah aktiva.

Perputaran Aktiva (Total Assets Turn Over) dapat dihitung dengan menggunakan rumus:

$$
\text { Total Assets Turn Over }=\frac{\text { penjualan }}{\text { Total aktiva }} \times 100 \%
$$

\section{METODE PENELITIAN}

Sesuai dengan tujuan penelitian ini, maka jenis penelitian yang digunakan adalah jenis penelitian kualitatif dengan menggunakan pendekatan deskriftif. Penelitian kualitatif adalah penelitian yang dinyatakan dalam skala numerik. (Algifani, 2009:3) sedangkan pendekatan deskriftif merupakan kegiatan mengumpulkan, mengelola dan kemudian menyajikan data observasi agar pihak lain dapat dengan mudah memperoleh gambaran mengenai sifat (karakteristik) objek dari data penelitian.

\section{HASIL DAN PEMBAHASAN}

Berdasarkan laporan keuangan yang telah diterima dari PT. Indonesia Kendaraan Terminal Tbk sebagai dasar penilaian kinerja keuangan perusahaan. Seperti yang dijelaskan sebelumnya yang menjadi tolak ukur dalam menilai kinerja keuangan perusahaan berupa rasio likuiditas, rasio solvabilitas, rasio profitabilitas, dan rasio aktivitas.

Tabel Perhitungan Rasio Likuiditas

\begin{tabular}{|c|c|c|c|c|c|}
\hline \multirow[b]{2}{*}{ Keterangan } & \multicolumn{5}{|c|}{ Tahun } \\
\hline & 2015 & 2016 & 2017 & 2018 & 2019 \\
\hline & & Rp188.799.47 & Rp244.699.51 & Rp717.026.39 & Rp630.179.19 \\
\hline Aktiva Lancar & Rp176.583.433 & 1 & 1 & 6 & 6 \\
\hline Hutang & & & & Rp151.765.55 & Rp191.597.08 \\
\hline Lancar & Rp70.923.331 & Rp79.362.538 & Rp97.689.861 & 1 & 5 \\
\hline Kas\& Setara & & & Rp174.600.83 & Rp556.526.56 & Rp491.547.35 \\
\hline Kas & Rp122.673.442 & Rp91.770.269 & 3 & 1 & 1 \\
\hline Saham Biasa & Rp10.000.000 & Rp10.000.000 & Rp10.000.000 & $\begin{array}{r}\text { Rp181.838.48 } \\
2\end{array}$ & $\begin{array}{r}\text { Rp181.838.48 } \\
2\end{array}$ \\
\hline
\end{tabular}

Sumber : Data Keuangan PT. Indoneisa Kenderaan Terminal,Tbk. Periode 2015-2019

\section{1) Current Ratio (Rasio Lancar)}

Hasil Perhitungan Current Ratio (Rasio Lancar) PT. Indonesia Kendaraan Terminal Tbk. Tahun 2015-2019 dapat dilihat pada tabel dibawah ini :

\begin{tabular}{|c|c|c|c|}
\hline \multirow{2}{*}{ Tahun } & Activa Lancar & Hutang Lancar & $\begin{array}{c}\text { Hasil Current } \\
\text { Ratio }\end{array}$ \\
\hline 2015 & 1 & 2 & $(1):(2) \times 100 \%$ \\
\hline 2016 & Rpl76.583.433 & Rp70.923.331 & $249 \%$ \\
\hline 2017 & Rp244.699.511 & Rp97.689.861 & $250 \%$ \\
\hline 2018 & Rp717.026.396 & Rpl51.765.551 & $472 \%$ \\
\hline 2019 & Rp630.179.196 & Rp191.597.085 & $329 \%$ \\
\hline
\end{tabular}


Berdasarkan Tabel diatas dapat dilihat tingkat persentase current ratio pada tahun 2016 mengalami penurunan sebesar 238\% jika dibandingan dengan tahun 2015 sebesar $249 \%$ dan pada tahun 2017 mengalami kenaikan sebesar 250\%. Dan hal yang sama terjadi pada tahun 2018 mengalami kenaikan yang sangat jauh yaitu sebesar $472 \%$ jika dibandingkan dengan tahun-tahun sebelumnya. Kemudian pada tahun 2019 mengalami penurunan sebesar 329\%. Sehingga dapat disimpulkan bahwa tingkat persentase current ratio PT. Indonesia Kendaraan Terminial Tbk mengalami fluktuasi perubahaan naik dan turun, dengan presentase tertinggi terjadi pada tahun 2018 dan terendah pada tahun 2016. Maka dari perhitungan diatas dikatakan perusahaan memperoleh kemampuan untuk membayar hutang lancar dimana aktiva lancarnya jauh lebih tinggi.

\section{2) Cash Ratio (Rasio Kas)}

Hasil Perhitungan Cash Ratio (Rasio Kas) PT. Indonesia Kendaraan Terminal Tbk. Tahun 2015-2019 dapat dilihat pada tabel dibawah ini :

\begin{tabular}{|c|c|c|c|}
\hline \multirow{2}{*}{ Tahun } & $\begin{array}{c}\text { Kas+Surat } \\
\text { Berharga }\end{array}$ & Hutang Lancar & $\begin{array}{c}\text { Hasil } \text { Cash } \\
\text { Ratio }\end{array}$ \\
\cline { 2 - 4 } & 1 & 2 & $(1):(2) \times 100 \%$ \\
\hline 2015 & Rp132.673.442 & Rp70.923.331 & $187 \%$ \\
\hline 2016 & Rp101.770.269 & Rp79.362.538 & $128 \%$ \\
\hline 2017 & Rp184.600.833 & Rp97.689.861 & $189 \%$ \\
\hline 2018 & Rp738.365.044 & Rpl51.765.551 & $487 \%$ \\
\hline 2019 & Rp673.385.839 & Rpl91.597.085 & $351 \%$ \\
\hline
\end{tabular}

Berdasarkan tabel diatas dapat dilihat tingkat persentase cash ratio pada tahun 2016 mengalami penurunan 128\% jika dibandingan dengan tahun 2015 sebesar 187\% dan tahun 2017 mengalami kenaikan sebesar 189\%. Dan hal yang sama terjadi pada tahun 2018 mengalami kenaikan yang sangat jauh yaitu sebesar $487 \%$ jika dibandingkan dengan tahun-tahun sebelumnya. Kemudian pada tahun 2019 mengalami penurunan sebesar 351\%. Sehingga dapat disimpulkan bahwa tingkat persentase cash ratio PT. Indonesia Kendaraan Terminal Tbk mengalami fluktuasi perubahan naik dan turun, dengan persentase tertinggi terjadi pada tahun 2018 dan terendah pada tahun 2016. Maka dari perhitungan diatas dapat dikatakan bahwa perusahaan dapat memenuhi kewajiban hutang jangka pendeknya.

Tabel Rasio Solvabilitas

\begin{tabular}{|c|c|c|c|c|c|}
\hline \multirow{2}{*}{ Keterangan } & \multicolumn{5}{|c|}{ Tahun } \\
\cline { 2 - 6 } & 2015 & 2016 & 2017 & 2018 & 2019 \\
\hline Total Aktiva & Rp226.717.050 & Rp264.941.265 & Rp334.737.537 & Rpl.255.245.128 & Rpl.264.868.846 \\
\hline Total Hutang & Rp70.923.331 & Rp79.362.538 & Rp97.689.861 & Rpl51.765.551 & Rpl91.597.085 \\
\hline Modal sendiri & Rpl55.793.719 & Rpl85.578.727 & Rp237.047.676 & Rpl.103.479.577 & Rpl.073.271.761 \\
\hline
\end{tabular}

Sumber : Data Keuangan PT. Indoneisa Kenderaan Terminal,Tbk. Periode 2015-2019

\section{1) Debt To Asset Ratio (Debt Ratio)}

Debt Ratio menunjukkan seberapa besar total aset yang dimiliki perusahaan yang didanai oleh seluruh krediturnya. Semakin tinggi debt ratio akan menunjukkan semakin berisiko perusahaan karena semakin besar utang yang digunakan untuk pembelian asetnya.

Hasil Perhitungan Debt to Asset Ratio (Debt Ratio) PT. Indonesia Kendaraan Terminal Tbk. Tahun 2015-2019 dapat dilihat pada tabel dibawah ini :

\begin{tabular}{|c|c|c|c|}
\hline \multirow{2}{*}{ Tahun } & Total Hutang & Total Asset & $\begin{array}{c}\text { Hasil Debt to } \\
\text { Asset Ratio }\end{array}$ \\
\cline { 2 - 4 } & 1 & 2 & (1):(2) x100\% \\
\hline 2015 & Rp70.923.331 & Rp226.717.050 & $31 \%$ \\
\hline 2016 & Rp79.362.538 & Rp264.941.265 & $30 \%$ \\
\hline 2017 & Rp97.689.861 & Rp334.737.537 & $29 \%$ \\
\hline 2018 & Rp151.765.551 & Rp1.255.245.128 & $12 \%$ \\
\hline 2019 & Rp191.597.085 & Rpl.264.868.846 & $15 \%$ \\
\hline
\end{tabular}


Berdasarkan tabel diatas dapat dilihat tingkat persentase Debt to Asset Ratio (Debt Ratio) pada tahun 2016 dan pada tahun 2017 mengalami penurunan sebesar 30\% dan 29\% jika dibandingkan dengan tahun 2015 sebesar 31\%. Dan hal yang sama pada tahun 2018 mengalami penurunan yang sangat jauh sebesar $12 \%$ jika dibandingkan dengan tahun-tahun sebelumnya. Kemudiaan pada tahun 2019 mengalami kenaikan sebesar 15\%. Dapat disimpulkan bahwa tingkat persentase Debt to Asset Ratio (Debt Ratio) PT. Indonesia Kendaraan Terminal Tbk mengalami fluktuasi perubahan naik dan turun, dengan presentase tertinggi terjadi pada tahun 2016 dan terendah pada tahun 2018. Maka dari perhitungan diatas dapat dikatakan bahwa perusahaan memiliki kewajiban hutang yang masih normal dimana hanya memakai paling banyak pada tahun 2016 sebesar $30 \%$ dari total aset perusahaannya.

\section{2) Debt To Equity Ratio}

Debt to Equity Ratio merupakan rasio yang digunakan untuk menilai utang dengan ekuitas. Untuk mencari rasio ini dengan cara membandingkam antara seluruh utang, termasuk utang lancar dengan seluruh ekuitas.

Hasil Perhitungan Debt to Equity Ratio PT. Indonesia Kendaraan Terminal Tbk. Tahun 2015-2019 dapat dilihat pada tabel dibawah ini :

\begin{tabular}{|c|c|c|c|}
\hline \multirow[t]{2}{*}{ Tahun } & Total Hutang & Total Ekuitas & $\begin{array}{c}\text { Hasil } \\
\text { solvabilitas }\end{array}$ \\
\hline & 1 & 2 & (1):(2) $\times 100 \%$ \\
\hline 2015 & Rp70.923.331 & Rpl55.793.719 & $46 \%$ \\
\hline 2016 & Rp79.362.538 & Rpl85.578.727 & $43 \%$ \\
\hline 2017 & Rp97.689.861 & Rp237.047.676 & $41 \%$ \\
\hline 2018 & Rpl51.765.551 & Rpl.103.479.577 & $14 \%$ \\
\hline 2019 & Rpl91.597.085 & Rpl.073.271.761 & $18 \%$ \\
\hline
\end{tabular}

Berdasarkan tabel diatas dapat dilihat tingkat persentase Debt to Equity Ratio pada tahun 2016 dan tahun 2017 mengalami penurunan sebesar $43 \%$ dan $41 \%$ jika dibandingan dengan tahun 2015 sebesar 46\%. Dan hal yang sama pada tahun 2018 mengalami penurunan yang sangat jauh sebesar 14\% jika dibandingkan dengan tahun-tahun sebelumnya. Kemudian pada tahun 2019 mengalami kenaikan sebesar $18 \%$. Sehingga dapat disimpulkan bahwa tingkat persentase Debt to Equity Ratio PT. Indonesia Terminal Tbk mengalami fluktuasi perubahan naik dan turun, dengan presentase tertinggi terjadi pada tahun 2016 dan terendah pada tahun 2018. Maka dari perhitungan diatas dapat dikatakan bahwa pengukuran kesehatan terhadap perusahaan baik dikarenakan dari 4 tahun berturut-turut tidak melebihi dari 50\%. Jadi bagus untuk investor untuk menanam saham di PT. Indonesia Kendaraan Terminal Tbk tersebut

Tabel Rasio Profitabilitas

\begin{tabular}{|c|c|c|c|c|c|}
\hline \multirow{2}{*}{ Keterangan } & \multicolumn{5}{|c|}{ Tahun } \\
\hline & 2015 & 2016 & 2017 & 2018 & 2019 \\
\hline Total Asset & Rp226.717.050 & Rp264.941.265 & Rp334.737.537 & Rpl.255.245.128 & Rpl.264.868.846 \\
\hline laba bersih & Rp94.914.257 & Rpl34.111.676 & Rpl74.706.802 & Rp220.633.556 & Rpl70.497.449: \\
\hline Laba Kotor & Rpl17.619.423 & Rpl63.041.687 & Rp206.788.458 & Rp249.998.152 & Rp217.643.653 \\
\hline $\begin{array}{c}\text { laba bersih setelah } \\
\text { pajak }\end{array}$ & Rp68.572.499 & Rp98.357.507 & Rpl30.154.955 & Rpl70.180.811 & Rpl35.301.570 \\
\hline Ekuitas & Rpl55.793.719 & Rpl85.578.727 & Rp237.047.676 & Rpl.103.479.577 & Rpl.073.271.761 \\
\hline Penjualan bersih & Rp247.027.927 & $\mathrm{Rp} 314.335 .510$ & Rp422.052.835 & Rp521.835.612 & Rp523.218.738 \\
\hline
\end{tabular}

Sumber : Data Keuangan PT. Indoneisa Kenderaan Terminal,Tbk. Periode 2015-2019 


\section{1) Gross Profit Margin (Margin Laba Kotor)}

Margin laba kotor atau disebut Gross Profit Margin bagian dari rasio profitabilitas memiliki tujuan untuk mengukur seberapa efisienkah usaha yang dilakukan manajemen dalam menekan HPP (harga pokok penjualan atau pembelian).

Adapun cara menghitungnya dengan adanya persentase dari penjualan dikurangi harga pokok penjualan dikenal dengan istilah laba dengan total penjualan. Semakin tinggi margin laba kotor, maka semakin baik dan secara relative semakin rendah harga pokok barang yang dijual.

Hasil Perhitungan Gross Profit Margin (Margin Laba Kotor) PT. Indonesia Kendaraan Terminal Tbk. Tahun 2015-2019 dapat dilihat pada tabel dibawah ini.

\begin{tabular}{|c|c|c|c|}
\hline \multirow{2}{*}{ Tahun } & Laba Kotor & Penjualan bersih & $\begin{array}{c}\text { Hasil Gross Profit } \\
\text { Margin }\end{array}$ \\
\cline { 2 - 4 } & 1 & 2 & $(1):(2) \times 100 \%$ \\
\hline 2015 & Rp117.619.423 & Rp247.027.927 & $48 \%$ \\
\hline 2016 & Rp163.041.687 & Rp314.335.510 & $52 \%$ \\
\hline 2017 & Rp206.788.458 & Rp422.052.835 & $49 \%$ \\
\hline 2018 & Rp249.998.152 & Rp521.835.612 & $48 \%$ \\
\hline 2019 & Rp217.643.653 & Rp523.218.738 & $42 \%$ \\
\hline
\end{tabular}

Berdasarkan tabel diatas dapat dilihat dari tingkat persentase Gross Profit Margin (Margin laba kotor) pada tahun 2016 mengalami kenaikan sebesar 52\% jika dibandingkan dengan tahun 2015 sebesar 48\%. Kemudian pada tahun 2017 mengalami penurunan sebesar 49\%. Dan hal yang sama pada tahun 2018 sebesar 48\% dan tahun 2019 sebesar 42\%. Sehingga dapat disimpulkan bahwa tingkat persentase Gross Profit Margin (Margin laba kotor) PT. Indonesia Kendaraan Terminal Tbk mengalami fluktuasi penurunan. Dengan persentase tertinggi pada tahun 2016 dan terendah tahun 2019. Maka dari perhitungan diatas dapat dikatakan bahwa perusahaan mampu menjual harga pokok produksi suatu barang dan jasa dengan jumlah yang normal dikarenakan laba kotor sebuah perusahaan sebanding dengan penjualan bersihnya.

\section{2) Net Profit Margin (NPM)}

Rasio yang digunakan untuk mengukur margin laba atas penjualan, rasio ini akan menggambarkan penghasilan bersih perusahaan berdasarkan total penjualan.

Hasil Perhitungan Net Profit Margin (NPM) PT. Indonesia Kendaraan Terminal Tbk. Tahun 2015-2019 dapat dilihat pada tabel dibawah ini :

\begin{tabular}{|c|c|c|c|}
\hline \multirow{2}{*}{ Tahun } & Laba Bersih & Penjualan bersih & $\begin{array}{c}\text { Hasil Net Profit } \\
\text { Margin }\end{array}$ \\
\cline { 2 - 4 } & 1 & 2 & (1) : (2) $x 100 \%$ \\
\hline 2015 & Rp94.914.257 & Rp247.027.927 & $38 \%$ \\
\hline 2016 & Rp134.111.676 & Rp314.335.510 & $43 \%$ \\
\hline 2017 & Rp174.706.802 & Rp422.052.835 & $41 \%$ \\
\hline 2018 & Rp220.633.556 & Rp521.835.612 & $42 \%$ \\
\hline 2019 & Rp170.497.449 & Rp523.218.738 & $33 \%$ \\
\hline
\end{tabular}

Berdasarkan tabel dapat dilihat tingkat persentase Net Profit Margin (NPM) pada tahun 2016 mengalami peningkatan sebesar 43\% jika dibandingkan dengan tahun 2015 sebesar 38\%. Kemudian pada tahun 2017 mengalami penurunan sebesar 41\%. Dan pada tahun 2018 mengalami kenaikan sebesar 42\%, kemudian pada tahun 2019 meengalami penurunan yang sangat jauh sebesar 
33\% jika dibandingkan dengan tahun-tahun sebelumnya. Dapat disimpulkan bahwa tingkat persentase Net Profit Margin (NPM) PT. Indonesia Kendaraan Terminal Tbk mengalami fluktuasi naik dan turun. Dengan presentase tertinggi pada tahun 2016 dan terendah tahun 2019. Maka dari perhitungan diatas dapat dikatakan bahwa perusahaan mendapatkan keuntungan dari hasil penjualannya.

\section{3) Return On Equity (ROE)}

Mengukur kemampuan perusahaan memperoleh laba yang tersedia bagi pemegang saham perusahaan.

Hasil Perhitungan Return On Equity (ROE) PT.Indonesia Kendaraan Terminal Tbk. Tahun 2015-2019 dapat dilihat pada tabel dibawah ini :

\begin{tabular}{|c|c|c|c|}
\multirow{2}{*}{ Tahun } & $\begin{array}{c}\text { Laba bersih } \\
\text { setelah pajak }\end{array}$ & Ekuitas & $\begin{array}{c}\text { Hasil Return On } \\
\text { Equity }\end{array}$ \\
\cline { 2 - 4 } & 1 & 2 & $(1):(2) \times 100 \%$ \\
\hline 2015 & Rp68.572.499 & Rpl55.793.719 & $44 \%$ \\
\hline 2016 & Rp98.357.507 & Rp185.578.727 & $53 \%$ \\
\hline 2017 & Rpl30.154.955 & Rp237.047.676 & $55 \%$ \\
\hline 2018 & Rp170.180.811 & Rpl.103.479.577 & $15 \%$ \\
\hline 2019 & Rp135.301.570 & Rpl.073.271.761 & $13 \%$ \\
\hline
\end{tabular}

Berdasarkan table diatas dapat dilihat tingkat persentase Return On Equity (ROE) pada tahun 2016 dan tahun 2017 mengalami kenaikan sebesar 53\% dan 55\% jika dibandingkan dengan tahun 2015 sebesar 44\%. Kemudian pada tahun 2018 dan tahun 2019 mengalami penurunan yang sangat jauh sebesar $15 \%$ dan $13 \%$ jika dibandingkan dengan tahun-tahun sebelumnya. Dapat disimpulkan bahwa tingkat persentase Return On Equity (ROE) PT. Indonesia Kendaraan Terminal Tbk mengalami fluktuasi naik dan turun, dengan presentase tertinggi pada tahun 2017 dan terendah pada tahun 2019. Maka dari perhitungan diatas dikatakan bahwa perusahan mengalami penurunan pendapatan bagi pemegang saham pada tahun 2018-2019 dikarenakan pengeluaran lebih banyak dari tahun sebelumnya.

Tabel Rasio Aktivitas

\begin{tabular}{|c|r|r|r|r|r|}
\hline \multirow{2}{*}{ Keterangan } & \multicolumn{5}{|c|}{ Tahun } \\
\cline { 2 - 6 } & \multicolumn{1}{|c|}{2015} & \multicolumn{1}{c|}{2016} & \multicolumn{1}{c|}{2017} & \multicolumn{1}{c|}{2018} & 2019 \\
\hline Total Asset & Rp226.717.050 & Rp264.941.265 & Rp334.737.537 & Rp1.255.245.128 & Rp1.264.868.846 \\
\hline Total Asset tetap & Rp27.627.482 & Rp56.980.524 & Rp76.343.980 & Rp251.630.478 & Rp354.391.477 \\
\hline Penjualan & Rp247.027.927 & Rp314.335.510 & Rp422.052.835 & Rp521.835.612 & Rp523.218.738 \\
\hline
\end{tabular}

Sumber : Data Keuangan PT. Indoneisa Kenderaan Terminal,Tbk. Periode 2015-2019

\section{1) Perputaran Aktiva (Total Assets Turn Over)}

Jenis rasio keuangan aktivitas yang digunakan untuk mengukur perputaran semua aktiva yang dimiliki perusahaan dan mengukur berapa jumlah penjualan yang diperoleh dari tiap rupiah aktiva.

Hasil Perhitungan Perputaran Aktiva (Total Assets Turn Over) PT. Indonesia Kendaraan Terminal Tbk. Tahun 2015-2019 dapat dilihat pada tabel dibawah ini :

\begin{tabular}{|c|c|c|c|}
\hline \multirow{2}{*}{ Tahun } & Penjualan & Total Asset & $\begin{array}{c}\text { Hasil Perputaran } \\
\text { Aktiva }\end{array}$ \\
& 1 & 2 & (1):(2) x100\% \\
\hline 2015 & Rp247.027.927 & Rp226.717.050 & $109 \%$ \\
\hline 2016 & Rp314.335.510 & Rp264.941.265 & $119 \%$ \\
\hline 2017 & Rp422.052.835 & Rp334.737.537 & $126 \%$ \\
\hline 2018 & Rp521.835.612 & Rpl.255.245.128 & $42 \%$ \\
\hline 2019 & Rp523.218.738 & Rpl.264.868.846 & $41 \%$ \\
\hline
\end{tabular}


Berdasarkan tabel diatas dapat dilihat tingkat persentase TATO pada tahun 2016 dan tahun 2017 mengalami kenaikan sebesar 119\% dan sebesar 126\% jika dibandingkan dengan tahun 2015 sebesar 109\%. Kemudian pada tahun 2018 dan pada tahun 2019 mengalami penurunan yang sangat jauh sebesar $42 \%$ dan $41 \%$. Dapat disimpulkan bahwa tingkat persentase TATO PT. Indonesia Kendaaran Terminal Tbk mengalami fluktuasi perubahan naik dan turun, dengan persentase tertinggi terjadi pada tahun 2017 dan terendah pada tahun 2019. Maka dari perhitungan diatas dapat dikatakan bahwa perusahaan mengalami penurunan penjualan dimana dengan total asset yang pada tahun 2016 dan tahun 2017 bisa menjual lebih banyak daripada total asset pada tahun 2018 dan tahun 2019.

\section{2) Perputaran Aktiva tetap (Fixed Asset Turn Over)}

Jenis rasio keuangan aktivitas yang digunakan untuk mengukur beberapa kali dana yang ditanamkan dalam aktiva tetap berputar dalam satu periode. Atau dengan kata lain, untuk mengukur apakah perusahaan sudah menggunakan kapasitas aktiva tetap sepenuhnya atau belum. Untuk mencari rasio ini caranya adalah membandingkan antara penjualan bersih dengan aktiva tetap dalam suatu periode.

Hasil Perhitungan Perputaran Aktiva Tetap (Fixed asset turn over) PT. Indonesia Kendaraan Terminal Tbk. Tahun 2015-2019 dapat dilihat pada tabel dibawah ini :

\begin{tabular}{|c|c|c|c|}
\multirow{2}{*}{ Tahun } & Penjualan & $\begin{array}{c}\text { Total Asset } \\
\text { tetap }\end{array}$ & $\begin{array}{c}\text { HasilPerputaran } \\
\text { aktiva tetap }\end{array}$ \\
\cline { 2 - 5 } & 1 & 2 & $(1):(2) \times 100 \%$ \\
\hline 2015 & Rp247.027.927 & Rp27.627.482 & $894 \%$ \\
\hline 2016 & Rp314.335.510 & Rp56.980.524 & $552 \%$ \\
\hline 2017 & Rp422.052.835 & Rp76.343.980 & $553 \%$ \\
\hline 2018 & Rp521.835.612 & Rp251.630.478 & $207 \%$ \\
\hline 2019 & Rp523.218.738 & Rp354.391.477 & $148 \%$ \\
\hline
\end{tabular}

Berdasarkan tabel diatas dapat dilihat tingkat persentase Perputaran Aktiva Tetap (Fixed asset turn over) pada tahun 2016 dan tahun 2017 mengalami penurunan sebesar $552 \%$ dan sebesar 553\% jika dibandingkan dengan tahun 2015 sebesar 894\%. Kemudian pada tahun 2018 dan pada tahun 2019 mengalami penurunan yang sangat jauh sebesar 207\% dan 148\%. Dapat disimpulkan bahwa tingkat persentase Perputaran Aktiva Tetap (Fixed asset turn over) PT. Indonesia Kendaraan Terminal Tbk mengalami Fluktuasi naik dan turun, dengan persentase tertinggi tahun 2017 dan terendah pada tahun 2019. Maka dari perhitungan diatas dapat dikatakan bahwa perusahaan mengalami penurunan memproduksi dikarenakan kurangnya efisien dalam memanfaatkan aset tetap sebab menurunnya tingkat penjualan pada tahun 2018 dan tahun 2019.

Dari hasil penelitian PT. Kinerja keuangan perusahaan secara keseluruhan dinilai dan diukur berdasarkan rasio keuangan yaitu Current Ratio, Cash Ratio, Debt Ratio, Debt to Equity Ratio, Gross Profit Margin, Net Profit Margin, Return On Equity, Total Asset Turnover, Fixet Asset Turnover. Dari penilaian setiap rasio keuangan yang digunakan untuk mengukur kinerja keuangan perusahan PT. Indonesia Kendaraan Terminal Tbk, berikut ini adalah hasil penelitian rasio keuangannya. 
Hasil Perhitungan Rasio Keuangan

\begin{tabular}{|c|c|c|c|c|c|c|}
\hline \multirow{2}{*}{ No } & \multirow{2}{*}{ Rasio Penilaian } & \multicolumn{5}{|c|}{ Tahun } \\
\hline & & 2015 & 2016 & 2017 & 2018 & 2019 \\
\hline 1 & Current Ratio (Rasio Lancar) & $249 \%$ & $238 \%$ & $250 \%$ & $472 \%$ & $329 \%$ \\
\hline 2 & Cash Ratio (Rasio Kas) & $187 \%$ & $128 \%$ & $189 \%$ & $487 \%$ & $351 \%$ \\
\hline 3 & Debt Ratio (Rasio Hutang) & $31 \%$ & $30 \%$ & $29 \%$ & $12 \%$ & $15 \%$ \\
\hline 4 & Debt to Equity Ratio (DER) & $46 \%$ & $43 \%$ & $41 \%$ & $14 \%$ & $18 \%$ \\
\hline 5 & Gross Profut Margin (Margin Laba Kotor) & $48 \%$ & $\mathbf{5 2} \%$ & $49 \%$ & $48 \%$ & $42 \%$ \\
\hline 6 & Net Profit Margin (NPM) & $38 \%$ & $43 \%$ & $41 \%$ & $42 \%$ & $33 \%$ \\
\hline 7 & Return On Equity (ROE) & $44 \%$ & $\mathbf{5 3} \%$ & $\mathbf{5 5} \%$ & $15 \%$ & $13 \%$ \\
\hline 8 & TATO (Perputaran Aktiva) & $109 \%$ & $119 \%$ & $126 \%$ & $42 \%$ & $41 \%$ \\
\hline 9 & Fixed Asset Turn Over (Perputaran Aktiva Tetap).. & $894 \%$ & $\mathbf{5 5 2} \%$ & $553 \%$ & $207 \%$ & $148 \%$ \\
\hline
\end{tabular}

Pada tabel di atas menunjukkan hasil perhitungan rasio keuangan penilaian kinerja keuangan perusahan PT. Indonesia Kendaraan Terminal Tbk. Secara umum hasil penilaian diatas setiap rasionya mengalami fluktuasi setiap tahunnya. Current Ratio (Rasio Lancar), Cash Ratio (Rasio Kas), TATO (Perputaran Aktiva), Fixed Asset Turn Over (Perputaran Aktiva Tetap) merupakan rasio yang fluktuasi pertumbuhan yang cukup signifikan. Sedangkan 5 rasio lainnya merupakan rasio yang fluktuasinya tidak terlalu signifikan.

\section{KESIMPULAN DAN SARAN}

Hasil Kinerja Keuangan PT. Indonesia Kendaraan Terminal Tbk periode 2015-2019 yang dianalisis dengan rasio keuangan, antara lain:

1. Tingkat rasio likuiditas yang dinilai dengan current ratio dan cash ratio pada PT. Indonesia Kendaraan Terminal Tbk periode 2015-2019 dalam kondisi yang baik. Hal ini mengindikasikan bahwa perusahaan telah mampu untuk memenuhi kewajiban jangka pendeknya.

2. Tingkat rasio solvabilitas yang dinilai dengan Debt Ratio (Rasio Hutang) dan Debt to Equity Ratio (DER) pada PT. Indonesia Kendaraan Terminal Tbk periode 2015-2019 masih dalam kondisi baik. Hal ini mengindikasikan bahwa perusahaan tidak banyak menggunakan hutanghutannya untuk membiayai aktiva yang dimilki.

3. Tingkat rasio profitabilitas yang dinilai dengan Gross Profit Margin (Margin Laba Kotor), Net Profit Margin (NPM), dan Return On Equity (ROE) pada PT. Indonesia Kendaraan Terminal Tbk periode 2015-2019 dalam kondisi yang baik. Hal ini mengindikasikan bahwa perusahaan telah mampu memanfatkan aktiva dan sumber daya yang dimiliki untuk memperoleh laba (keuntungan) yang dicapai.

Tingkat rasio aktivitas yang di nilai dengan Total Asset Turn Over (Perputaran Aktiva) dan Fixed Asset Turn Over (Perputaran Aktiva Tetap) pada PT. Indonesia Kendaraan Terminal Tbk periode 2015-2019 dalam kondisi yang cukup baik. Dapat dilihat mengalami penurunan pada tahun 2018 dan pada tahun 2019, hal ini mengindikasikan bahwa perusahaan kurang efesien dan optimal dalam memanfaatkan dan mengelola aktiva yang dimiliki dalam menghasilkan pendapatan.

Berdasarkan kesimpulan yang telah didapatkan dari hasil analisis penilaian kinerja keuangan PT. Indonesia Kendaraan Terminal Tbk periode 2015-2019, maka saran yang dapat disampaikan adalah sebagai berikut: 
1. PT. Indonesia Kendaraan Terminal Tbk sebaiknya mampu mempertahan atau mampu meningkatkan tingkat kinerja keuangan yang telah diperoleh sehingga dapat bersaing lebih unggul dengan perusahaan-perusahaan lain terutama yang sejenis.

2. PT.Indonesia Kendaraan Terminal Tbk sebaiknya melakukan evalusi kebijakan berkaitan dengan rasionya yang mengalami penurunan yang sangat jauh atau sedikit kurang baik. Seperti dalam rasio Total Asset Turn Over dan Fixed Asset Turn Over. Dengan pemilihan kebijakan yang baik dan konsisten, diharapkan dapat meningkatkan penilaian kinerja keuangan perusahaan.

Dari penelitian diatas dapat dilihat bahwa kinerja keuangan perusahaan PT. Indonesia Kendaraan Terminal Tbk periode 2015-2019 masih dalam kondisi normal atau baik. Akan tetapi untuk penelitian selanjutnya sebaiknya dapat mengukur dan menganalisis beberapa rasio lain sehingga hasil penilaian kinerja keuangan PT. Indonesia Kendaraan Terminal Tbk dapat dilihat secara luas dan terperinci.

\section{DAFTAR PUSTAKA}

Dwi Prastowo dan Rifka Julianti. 2002. Analisis laporan Keuangan. Konsep dan Aplikasi. Edisi Kedua. UPP AMP YKPN, Yogyakarta.

Ery Mutiara Nurkamalina, 2012 "Analisis Laporan Keuangan Sebagai Alat Penilaian Kinerja Keuangan"

Fahmi, Irham. 2011. Analisis Laporan Keuangan. Bandung: Alfabeta.

Falikhatun dan Putri Nugrahaningsih. 2007. Analisis Laporan Keuangan. Surakarta: FE UNS.

Hanafi, Mamduh dan Abdul Halim. 2003. Analisis Laporan Keuangan. Edisi Revisi. Yogyakarta: UPP AMP YKPN.

Ikatan Akuntan Indonesia, 2002, Standar Akuntansi Keuangan. Jakarta: PT. Salemba Empat Patria. Ikatan Akuntan Indonesia. 2009. Standar Akuntansi Keuangan. Jakarta: PT. Salemba Empat Patria. I Made Sudana. 2011. Manajemen Keuangan Perusahaan Teori dan Praktik. Jakarta: Erlangga Mahmudi . 2007. Analisis Laporan Keuangan Pemerintah Daerah, Yogyakarta: UPP STIM YKPN. Mahmudi. 2007. Manajemen Kinerja Sektorpublik. Yogyakarta: Unit Penerbit Dan Percetakan Sekolah Tinggi Ilmu Manajemen YKPN.

Mulyadi. 2001. Akuntansi Manajemen: Konsep, Manfaat, dan Rekayasa. Jakarta: Salemba Empat. Munawir, S. 2010. Analisis Laporan Keuangan. Yogyakarta: Liberty.

Marianno Willam J.S, 2017, "Analisis Rasio Keuangan Untuk Menilai Kinerja Keuangan Perusahaan (Studi Kasus Di PT. Telekomunikasi, Tbk)"

Mastiur Sandora Manurung, 2019 "Analisis Laporan Keuangan Untuk Menilai Kinerja Keuangan Pada PT. Austindo Nusantara Jaya, Tbk Yang Terdaftar Di Bursa Efek Indonesia Periode 2013-2017."

Masnuripa Harahap, 2018 “Analisis Rasio Likuiditas Sebagian Alat Penilaian Untuk Mengukur Kinerja Keuangan Pada PT. Widyahusada Tbk"

Soemarso S.R, (2002), Akuntansi Suatu Pengantar, Jakarta: Salemba Empat.

Sugiyono. 2013. Metode Penelitian Pendidikan Pendekatan Kuantitatif, Kualitatif, dan R\&D. Bandung: Alfabeta.

Jhoni Kurniawan, 2017 "Analisis Kinerja Keuangan Perusahaan Food And Beverage Yang Terdaftar Di Bursa Efek Indonesia Periode 2011-2015."

Amthy \& Shella, 2019 "Analisis Rasio Keuangan Untuk Mengukur Kinerja Keuangan Pada PT. Gas Negera Tbk Periode 2013-2017 (Berdasarkan Keputusan Menteri BUMN Nomor: KEP100/MBU/2002)."

www.idx.co.id 